\title{
EDUCACIÓ, VALORS I GUERRES
}

El món de l'ensenyament s'esmerça, en el dia a dia, a copsar el ritme dels fets, a fer seves les preocupacions del present. Bons exemples d' aquesta actitud són el progressiu interès pel multiculturalisme i els seus reptes, i l'educació per al civisme, el diàleg i el respecte. Els creixents corrents migratoris han posat damunt la taula la necessitat d'educar per a la convivència; la diversitat cultural és una realitat nova per a la qual ens hem de preparar. Prendre part en tota mena d'activitats basades en el diàleg i la participació és, per als nens, una bona base per a afrontar el seu rol com a futurs ciutadans.

Convivència i democràcia són, sens dubte, elements essencials de la tan sovint invocada educació en els valors. Des dels continguts actitudinals explicitats al currículum, passant per les diferents formes de transversalitat i arribant, finalment, a la pràctica diaria, a les maneres de fer i comunicar-nos dia a dia, els valors han de ser un tema d'importància cabdal. I entre ells, democràcia, convivència, respecte a l'altre, diàleg i consens han de tenir un lloc destacat.

Vet aquí un paràgraf assumible, possiblement, pel cent per cent dels mestres i professionals de l'educació. A vegades, però, la realitat que ens envolta ens fa conscients del cami que queda per recórrer. La dinàmica dels fets ens colpeix amb tota la seva cruesa. Ens posa abruptament al davant la urgència d'emfasitzar aquests temes.
Respecte a l'altre, consens? Les notícies del que ha succeït al món a les darreres setmanes ha impactat milions de consciències. L'avarícia esdevé un cop més motor de les coses. Els poderosos imposen el seu "nou ordre". Assistim atònits a complicitats vergonyoses de dirigents de segona fila àvids de notorietat, ansiosos de prebendes i canongies.

Com no podia ser d'altra manera, les escoles han fet bandera de la seva funció d'educar en valors, i s'han multiplicat els actes en favor de la pau. Quan els més "grans" dinamitaven els fòrums internacionals de diàleg, ens esforçàvem perquè els més petits comprenguessin la importancia de parlar, consensuar i conviure. La resposta del món de l'ensenyament davant la guerra ha estat massiva, creativa, àgil, amb la urgència que calia. A les escoles d'ensenyament primari, els coloms blancs de paper als vidres de les aules, els signes de la pau traçats pels mateixos nens al pati, les cartes fetes pels nens i nenes a dirigents que mai no les llegiran (tan ocupats com estan a esbotzar) reflectien un sentiment que s'escampava com taca d'oli. Els joves han despertat inesperadament d'anys d'indiferència generalitzada. Els centres d'ensenyament secundari han fet sentir la seva veu. Les universitats no s'han quedat enrere. Han esdevingut fòrums de debat social, focus d'opinió amb veu pròpia. Enhorabona. 